\title{
A Research on Children's Representations in the Turkish Press in the Context of Ethical Responsibility of the Media
}

Application Date: 20.11 .2020

Accepted Date: 19.12 .2020

Publishing Date: 30.12 .2020

\author{
Petek Durgeç ${ }^{1}$ \\ Ege University \\ petekdurgec@gmail.com
}

(iD) ORCID: 0000-0002-5927-145X

\begin{abstract}
The concept of child has attracted a lot of attention in the media from the past to the present. The news that are prepared by highlighting the element of child has the feature of attracting much more attention. This high interest of the news about children may also cause the possibility of children being abused by the media. Therefore, the news should be written very carefully in order not to harm children, who are the subject of the news, emotionally. Mostly, just being mentioned in the news can be considered hazardous to the child. For all these reasons, the representations in the news texts are of great importance. The purpose of this study is to reveal how children are represented in the news in the context of the ethical responsibility principle. In this context, content analysis of 186 child themed news which were published between determined randomly 1 June to 15 June 2020 in Turkey's four newspapers with the largest circulation, namely Hürriyet, Sabah, Posta and Sözcü was performed. In this study, which aims to reveal the presentation form of children's news in the context of the ethical responsibility of the media, it was shown that children are mostly presented as the subject of forensic news. Children are represented mostly in forensic news in Sözcü, Hürriyet, Sabah and Posta which have the highst circulation rates in Turkey. This situation indicates that children are represented in newspapers by judicial events. Forensic news is followed by news of illness and physical violence. On the other hand, news categories in which children are represented he least are success/talent and deceased. While it is expected that children will take place in the categories of school and success/talent the most, the opposite is encountered. The data obtained are intended to demonstrate the remarkable nature area in terms of representation of children in the Turkish Press.
\end{abstract}

Keywords: Media, Child, Press, Representation, Ethics.

\footnotetext{
${ }^{1}$ Ph.D. Research Assistant. Ege University.
} 


\title{
Medyanın Etik Sorumluluğu Bağlamında Türk Yazılı Basınındaki Çocuk Temsilleri Üzerine Bir Araştırma
}

BaşvuruTarihi: 20.11.2020 Yayın Kabul Tarihi: 19.12 .2020 Yayınlanma Tarihi: $\quad 30.12 .2020$

\author{
Petek Durgeç ${ }^{2}$ \\ Ege Üniversitesi \\ petekdurgec@gmail.com \\ ORCID: 0000-0002-5927-145X
}

\begin{abstract}
ÖZET
Geçmişten günümüze medyada son derece ilgi gören bir olgu olan çocuk ögesini öne çıkararak hazırlanan haberler, yayınlandıkları mecralarda fazlaca ilgi çekebilme özelliğine sahiptir. Çocuk temsillerinin yer aldığı haberlerin yüksek ilgi uyandırma özelliği, çocukların medya tarafından duygusal olarak istismar edilebilmesi açmazını da beraberinde getirmektedir. Haber metinlerinde özne olarak yer alan çocukların duygusal olarak zarar görmemesi için haberlerin etik kodlara bağlı kalınarak ve çocuğu koruyan bir retorikle hazırlanarak yayınlanması gerekmektedir. Bu çalışmanın amacını, etik sorumluluk ilkesi bağlamında Türk basınında çocukların haberlerde nasıl temsil edildiğini ortaya koymak oluşturmaktadır. Bu bağlamda Türkiye'nin en yüksek tirajlı dört gazetesi olan Hürriyet, Sabah, Posta ve Sözcü gazetelerinde rastgele olarak belirlenen 1 Haziran-15 Haziran 2020 tarih aralığı boyunca yayınlanan çocuk temalı 186 habere içerik analizi gerçekleştirilmiştir. Medyanın etik sorumluluğu bağlamında çocuk haberlerinin sunum biçimini ortaya koymayı amaçlayan bu çalışma sonucunda, çocukların gazetelerde en fazla adli haberlerin öznesi olarak sunulduğu sonucu ortaya çıkmıştır. Incelemeye alınan Türkiye'nin en yüksek tirajlı gazeteleri olan Sözcü, Hürriyet Sabah ve Posta gazetelerinde çocuklar en fazla adli haberlerde özne olarak kullanılmıştır. Adli haberleri hastalık ve fiziksel şiddet haberleri takip etmektedir. Çocukların en az oranda temsil edildiği haber kategorileri ise başarı/yetenek ve ölüm olarak karşımıza çıkmaktadır. Elde edilen veriler Türkiye'de yazılı basında çocukların temsil alanlarını ortaya koyması açısından dikkat çekici nitelik taşımaktadır.
\end{abstract}

Anahtar Kelimeler: Medya, Çocuk, Basın, Temsil, Etik.

\footnotetext{
${ }^{2}$ Araştırma Görevlisi Doktor. Ege Üniversitesi.
} 


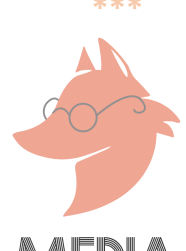

\section{INTRODUCTION}

Social improvements are of great importance for the development of countries and their establishment in an internationally respected position. Advances in the development, education and inclusion of children will also positively affect social welfare. For this reason, any activity for children should be evaluated seriously. At this point, the importance of the media is an undeniable fact. The media has to be careful and sensitive both in the content of the news and in the representations that are created regarding of children. Therefore, it is required by the media to make well-elaborated news especially about juvenile delinquency.

The representation of meanings and events produced by the media concerning children's rights is one of the frequently discussed topics. At the center of these discussions the concern that the media can create permanent prejudices in the minds through the representations is suited. It is known that children are represented deficiently and incorrectly in the media when they are able to be mentioned. Moreover, in many parts of the world, children are faced with life-threatening violations and many adverse conditions such as inability to access opportunities in education, health, social and digital fields.

Children should be paid more attention as they are the representatives of the future. All institutions and organizations in the society, especially the state, have responsibilities for the mental and physical upbringing of children. Thus, the media, which has an important effect on shaping the society, has a much greater responsibility in this regard. Press intuitions who is strongly able to set an agenda and orient the society according to subjects that they should be thinking about, should provide attentively prepared messages. Preparing and publishing the news with false messages may affect the lives of children negatively. For all these reasons, the representations in the news texts are of great importance.

The aim of this study is to reveal how children are represented in the news in which they take place by focusing on the ethical responsibility of the media. Firstly, up-to-date information on national and international regulations regarding children will be mentioned. Secondly, the ethical regulations related to children in the media will be shown by reviewing the literature that exists on the representation of children in the media of the world and Turkey. Later, the related finding will be shared. For this purpose, 186 news between 1 June 2020 and 15 June 2020 where children are positioned as subjects in the first four newspapers of Turkey according to their high circulation rates which are Sözcü, Hürriyet, Sabah and Posta were examined by content analysis method. In the theoretical part of the study, the principles of ethical responsibility and newsworthiness concepts are discussed and the legal regulations explaining how news about children should be published are provided. 


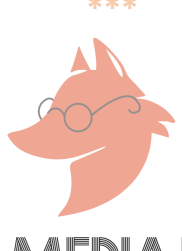

\section{Children on Legal Regulations in Turkey and the World}

Children are one of the most vulnerable groups of societies as they would not be capable of protect themselves from harmful consequences of exploitation and neglect. Moreover, childhood is a period in which physical, mental and social development continues rapidly. Therefore, they need special protection including legal ones. Legal regulations concerning children have emerged to meet these requirements. Many private and public institutions such as international organizations, governments and media organizations considered children as individuals to be protected and set binding laws and obligations for their protection.

Children's rights are not in conflict with adults' rights and it is part of human rights law. On the other hand, children having special rights different than adults, means that they have special rights due to their development needs. From the moment the child is born, he/she has the same personal rights as adults. Therefore, the expression everyone used in human rights declarations, conventions and constitutions also includes the child. Children's rights are benefits protected by legal rules for the physical, mental, emotional, social and moral development of children in freedom and dignity, in a healthy and normal manner. The special protection of children constitutes the most fundamental element of international agreements in legal terms. The principle of equality, which is the highest value of law in every region of the world, requires special protection of children.

In the development of human rights, civil and political rights should be considered together with economic and social rights. In this respect, the state has negative and positive obligations in the protection of children's rights. The state must comply with convention norms related to children's rights and protect children. It should take measures to implement children's rights in all areas of life. The concept of protection of human rights includes the state preventing violation of rights by non-state actors. Therefore, the state should prevent the violation of children's rights by non-state actors (Karaosmanoğlu, 2003).

It is not possible to isolate children's act from the economic and social structure of the society and to exclude the historical and class background (Balo, 2005, p.47). Children's rights emerged after the recognition of human rights and constitutional fundamental rights for children under 18. In children's rights, international human rights and constitutional fundamental rights are reinforced not only for children but also for the whole society since the childhood of the individual affects the adulthood period. In this sense, embracement of children's rights can be regarded as the most beneficial investment, the most productive contribution to the democratic culture and future of a society. The fact that the child is being consider as weaker than adults in terms of demanding his or her rights, is also one of the reasons for neglect of children's rights (Gemalmaz, 2002, p. 26). 


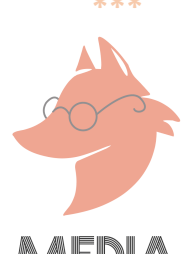

Cilt / Vol: $03-$ Sayı / No: $02 \quad$ | e-ISSN: 2757-6035

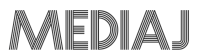

International conventions regulate children's rights and set out criteria that should be taken as reference in terms of development and progress made by countries. In this context, the United Nations Convention on the Rights of the Child was adopted at the 44th General Assembly Meeting of the United Nations on 20 November 1989. The document submitted for the approval of the member states was approved by many governments in a short time and became the most widely accepted human rights declaration in history (Dikmen, 1998).

The United Nations Convention on the Rights of the Child, ratified by the Republic of Turkey on December 23, 1994 and entered into force on January 27, 1995. The contract, which consists of 54 articles, includes provisions regarding the determination and resolution of the problems faced by children in their daily lives as well as the cases of abuse and exploitation. Children's rights in the convention applies equally to all children, regardless of ethnicity, social difference, disability, birth or birth-related characteristics. In addition, it is guaranteed by the participating states that they treat children equally under all conditions, with the convention (Ates, 2011). The Convention has been prepared in a structure that considers the social and cultural characteristics of societies while determining the basic principles in the field of children's rights. The convention is also the most basic legal text protecting children's rights in international law. Moreover, it has a legislative nature by including to the constitution of Republic of Turkey as law.

The United Nations Convention on the Rights of the Child recognizes that children have special needs. In addition, all states that are parties to the convention voluntarily recognize and accept their obligations when they sign the agreement. This acceptance means that states agree to implement this agreement, to control of the realization of rights, and to meet the needs of people within their jurisdiction (Heffinck, 1999). The Convention is the only legally binding international document that clearly and harmoniously determines human rights standards for children (Tiryakioğlu, 2000, p. 41). The Convention regulates the rights of children and the obligations of states for the realization of these rights. The children's rights that are regulated and guaranteed by the convention cannot be separated from the concept of human rights in general. Children's rights are the forms of personal human rights such as life, education, personal safety and fair trial, which are guaranteed especially for children (Karaosmanoğlu, 2003).

The basic principles under the convention are non-discriminative and for the best interests of the child. These four basic children's rights have been determined as creating a media space that includes children's views within the framework of the right to life and development, the right to education, the right to non-discrimination and the right to participate. Media outlets are expected to respect the four basic children's rights mentioned. For this, media members should establish systems that will provide them with self-control and internal auditing policies (Inceoğlu, 2008). 


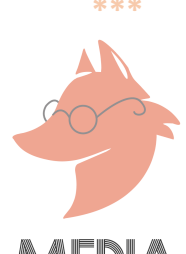

Turkey has been under obligations towards the implementation of the provisions of the Children's Rights Convention which has been integrated to domestic law. Making the necessary changes in the domestic law and providing the institutional infrastructure are the requirements of the basic principle expressed as respect for children's rights (Küntay, 2000).

Articles 16, 17 and 19 of the United Nations Convention on the Rights of the Child are articles related to the media coverage of children. Article 16 guarantees the principle of inviolability of private life. According to the relevant article, children have the right to be protected from external interference, libel and unjust accusations in their private, family and domestic life and their communication. Article 17, on the other hand, is about the right to be informed and it is about the need for states to promote the mass media to disseminate information that will provide social and cultural benefits to children and to protect children from harmful publications. According to the 19th article on child abuse and neglect, the state should provide social programs that aims to treat children who are subjected to harmful behavior of all kinds of maltreatment by his family or other caregivers to protect them sufficiently. Therefore, it is understood from these three articles that while making news when the child is the subject, their dignity and reputation should be protected, private life should be respected, and they shall not be accused unjustly (Salihoğlu, 2007).

The framework for the protection of children in Turkish law was established by the 1982 Constitution. In addition to the basic principles specified in the Constitution, rules on the protection of children's rights are also regulated in the Civil Code. Taking the Civil Code from Switzerland is an important step in juvenile law. The first Civil Code of 1926, which includes contemporary provisions on children, was revised in 2002 in accordance with the changing social and economic conditions. All provisions that may be related to children in the Civil Code have been rearranged and made in accordance with internationally accepted standards (Özlü, 2002, p.65).

Issues such as lack of education, exclusion and violence that threaten the rights of children can only be overcome with the progress of the economic and social structure of the society. It will be very difficult to realize children's rights in a country where democracy and social state do not exist. Consequently, people who have not internalized the culture of democracy and whose social perspective has not developed cannot be expected to adopt a point of view in favor of children's rights.

\section{Ethical Responsibility and Journalism}

Responsibility and ethics are being considered synonymous in journalism. There is a direct link between all moral duties and social responsibilities. The most original meaning of the concept of morality, in its simplest form, is the ability to put oneself in the place of the other. Legal 


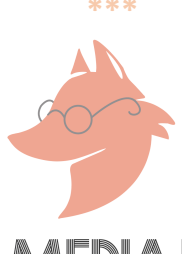

Cilt / Vol: $03-$ Sayı / No: $02 \quad$ | $\quad$ e-ISSN: 2757-6035

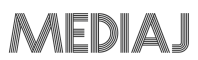

regulations about the press are a driving force that creates the behavioral codes of journalists. Moreover, legal regulations have the power of sanction. The issue of ethics in the press and in the media in general is as important as the legal regulations. Journalism is one of the first professions to have ethical rules in addition to legal regulations (Girgin, 2003, p. 57). The ethical principles that guide journalists while performing their journalism profession are of great importance in the media environment. The case of ethics emphasizes that journalism carries public interest (Çambay, 2016, p. 110).

Media ethics often refers to a tradition that dictates what should and should not be done and which behavior can be acceptable. In media ethics, freedom and responsibility go hand in hand. It has introduced some rules that set limits on personal freedom and set the obligations. These rules are not a sacred writing that every journalist swears to be strictly loyal. These are only a guide that can become functional if the journalist has a sense of ethics. These rules, which have not been published by a government, can be published by a national organization such as professional associations, media owners' associations, journalist's associations, daily newspaper or a broadcast network, or they can be published as the product of an international organization such as the International Federation of Journalists (Bertrand, 2004, p. 35). Ethical violations and problems in news about children often occur in negative events where children become part of the news. There are ethical principles guiding journalists on how to deal with children who are victims or suspects in forensic news such as rape, theft, drugs, suicide, and injury, and how children should be identified.

One of the most important features of journalism ethic rules is that they are spread over a very wide geography. There are different ethical rules of journalism in many parts of the world (Belsey, Chadwick, 1998, p. 53). According to the ethical principle of The Society of Professional Journalists, journalists should show special sensitivity in news related to children and carefully avoid disclosing the identities of child defendants and rape victims. The British Press Complaints Commission ethical principle states that in cases related to children, editors must prove that there is an exceptional public interest that will prevail over the interests of children. The press should not reveal the identities of children under the age of 16 who have been involved in sexual assault as victims or witnesses, even if not prohibited by law. Special care should be taken when processing news about children, according to the ethical principle of the Spanish Press Federation. The disclosure of the names of victims of crime or the publication of materials that give rise to the identity of victims should be avoided. Journalists need to pay special attention, especially when writing news on sexual crimes. Also, journalists should refrain from interviewing children and taking photos in such crimes (Irvan, 2005, p. 82).

According to Turkish Journalists' Declaration of Rights and Responsibilities, in the criminal cases related to children, regardless of being victims, witnesses or defendants in sexual assault; full names and photographs of minors under the age eighteen should not be published. According 


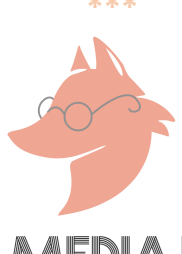

to the charter, the journalist should not interview or attempt to capture images of the child without the consent of an elder or other person responsible for the child in situations that could affect the child's personality and behavior. In news about children, it is stated that it should be aimed to draw attention to the problem (www.tgc.org.tr).

Professional associations of journalism pay special attention to news on children. They especially emphasize the issue of concealing the identity of child victims. Turkish Journalists' Association of the ethical principles, in terms of news related to children contain more certain expressions than their counterparts in Europe. However, the main problem is not to have a clear and easy to understand principle, but whether this principle is applied in practice (irvan, 2003, p. 83). A theoretically and properly written ethical principles will not work if there are no professionals ready to adopt and implement them. On the other hand, newspapers have the function of addressing individuals with different perception levels at the same time. Therefore, elements of simplification, summarization, and being unscientific for clarity are dominant in the contents. In order to prevent this situation, which brings problems such as tabloidization, it is necessary to adhere to unshakable ethical principles while preparing children's news.

\section{Newsworthiness and Children}

What is called newsworthy is the professional codes that mass media authorities use during the production, selection, formulation and publication of actions or discourses. Newsworthiness is the format used by industrialized news organizations during their production. They are also other value judgments brought by the journalists besides the personal value judgment of them. It is known that these value judgments undergo changes according to time, ground and societies or leave their places to new ones (Girgin, 2003, p. 80). Today, for journalists, newsworthiness is expressed as an abstract concept that cannot be easily defined.

The greater the news value of an event, the more likely it is to have media coverage. It is possible to collect news values under five main headings. These are; timeliness, proximity, importance, result and attractiveness. Unusualness, adventure, excitement, things worth seeing and love are among the subjects that constantly attract people's attention. Although children are not the target audience of news programs, they are newsworthy since they rank first among the topics that attract people (Tokgöz, 2000, p. 180). However, it is a matter of discussion if this situation solves the problems of children, creates an awareness or has an effect on taking serious steps in this regard.

Unusual, hard to believe, or embarrassing events are published as news, with an attempt to generate excessive attention to the crime or disaster in question. In addition, the language of the news is used to provoke or excite the reader (Cheit, 2002). This is because newsworthiness is often structured in line with the profile of the target audience. The topics that a newspaper 


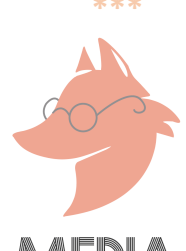

or magazine chooses as newsworthy depend on who the target audiences are and what they expect. It is very important that the news prepared by the journalist is structured in order to attract the attention of the reader.

Today, the phenomenon of attracting people's attention in journalism has completely dominated in the profession. While attracting the attention of people in journalism, it is emphasized that it distorts, confuses and simplifies the news values. It has become the most preferred way to add items of interest to the news. Attracting people's attention must have certain limits. On the other hand, news value also differs according to mass media. For example, the perspective of a newspaper, television channel or magazine on the news varies according to the target audience.

In many countries, children's news is at the top of the agenda. However, this situation does not have an effect on the solution of children's problems in the world. This is because of the language used by the media. Since the fiction of the news is dramatic, the reader or the audience moves away from the reality of the event. As the objects of the news become abstract, the background and meaning of the news disappear. The media encodes the world in the form of an information world of infancy at the one end, adulthood at the other, and adult childhood in the middle. The fact that the same source sends a message to all individuals from all ages, social and social environments, and cultural levels that the media tries to place in the information society is important in terms of eliminating the difference between children and adults (Şirin, 2006, p. 78).

Thanks to the media, the child is in the midst of violence, on the edge of hunger, in the lap of a politician, on the street and everywhere. Children have now become objects of show that society is accustomed to see. The media only reports on events that are different than usual, are newsworthy, and affect social perception (Boulahanis \& Heltsley, 2004). The reason why children are used in news is due to its importance as news value rather than its feature of enlightening the news. However, the media uses children in the news regardless of the basic problems of children.

Children are mostly used in the news as victims. When the victim is a child, the disaster becomes particularly visible. Especially events involving a large number of suspects and victims become newsworthy. However, there are many reasons for people to be attracted by seeing images of desperate children. Crimes against specific groups of victims such as children attract more attention than others. Young and older victims are more likely to be reported than other victims (Cheit, 2002).

The media often describe children simply as "silent victims" or "lovely innocents". The concept of "innocent child" has been activated by politicians and media in developed countries (Selwyn, 2003). It is clear that striking news, such as sexual abuse of a child, has a strong news value. The 


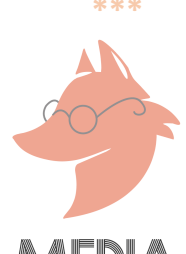

media prefers to report incidents of the seemingly naive and innocent victim and the evil criminal. This situation supports the high coverage of news about children in the media. The moral meaning of such news is too much. This news is instrumental to cause strangeness, unusualness, dramatic or fame (Cheit, 2002).

On the other hand, the media sometimes portray children as very dangerous individuals. There is a dichotomy in the style of the media in the news about children. Children, who are sometimes described as the most innocent beings in the world, lose all their innocence when they get involved in an event that is not approved by the society and become news since the purity of victimization is a cultural need (Moeller, 2002). Especially children involved in crime are shown by the media as having lost their innocence and this constitutes a violation of rights.

Media professionals should remind the public that children deserve respect for their personal assets (UNICEF, 2005). Moreover, the media itself must respect children's personal assets. In particular, media professionals need to be specially trained on how to broadcast news about children who are in the position of a victims. In this way, the risk of secondary victimization of the child who is the subject of the news because of being the victim will be minimized (Collings, 2002).

The news prepared by the media should be edited by taking children's rights into account. It should not be forgotten that children's rights are primarily human rights. Generally, it is not known whether there is a violation of rights in the content of the news or it is ignored even if there is a violation. The media cannot be expected to be sensitive to children's rights, as long as the purpose of news about children is to attract more attention and to generate higher earnings. This kind of understanding perceives the child only as the object of the news or as a news value. This situation leads to an approach that ignores the human rights of the child.

Journalists are defenders of human rights. Thus, they should sue a language that respects the disadvantaged groups of the society in their news. They are obliged to expose the abuses of power and to draw attention to human rights. Through their work, they encourage governments and non-governmental organizations to influence changes that will improve people's quality of life. Nevertheless, nowadays, the media often display appearances that expose the plight of children who are caught up in events beyond their control or abused by adults. However, the media should take into account the perspective of children. Children need to be featured in the media as they deserve.

\section{METHODOLOGY}

The aim of this study is to reveal how and in which way children's news are included in the Turkish press within the context of the ethical responsibility concept and to determine the 
representations created regarding children. Another main objective of this study is to revel the absences of journalism on children by taking the news published in Turkey into consideration and to develop suggestions for the solution. In this context, the news about children published between determined randomly 1 June and 15 June 2020 in four newspaper of national media with the highest circulation rates namely Sözcü, Sabah, Hürriyet and Posta are analyzed by using content analysis method.

Content analysis is a method for analyzing recorded texts and focuses on the information the message contains, carries and transmits (Yıldırım; 2015, p. 106). Content analysis technique aims to eliminate subjective factors in understanding and interpreting a discourse (Bilgin; 2006, p. 1). In addition to the numerical analysis of the news on children in the press, a general evaluation was made by analyzing the news in terms of content and subject.

The questions to be answered in the research are:

1. In which regards did children take part in the examined newspapers?

2. How are children represented in the news in the examined newspapers?

3. How are the photographs and identity information of children presented in the news in the examined newspapers?

\section{Research Findings}

Within the scope of the research, 60 newspapers published between 1-15 June 2020 were examined and a total of 186 news about children were found in the examined newspapers. In the research, news with children themes that appeared on the main page, inside page and cover pages of the newspapers were evaluated. The frequency of children's news in each of the newspapers namely Sözcü, Sabah, Hürriyet and Posta, distribution of children's news within the analyzed periods, and categories in which children's news appeared in the newspapers stand out were analyzed.

Of the 186 news in the study, 29.57\% (55) were in Posta, 27.42\% (51) were in the Sözcü, 22.04\% (41) in Hürriyet, $20.97 \%$ in (39) Sabah newspapers.

Table 1. Distribution of the Topics According to Newspapers

\begin{tabular}{|l|c|c|c|c|c|c|c|c|}
\hline $\begin{array}{l}\text { Subject of } \\
\text { the news }\end{array}$ & \multicolumn{3}{|c|}{ Hürriyet } & \multicolumn{3}{c|}{ Sabah } & \multicolumn{3}{c|}{ Posta } & \multicolumn{3}{c|}{ Sözcü } \\
\hline & $\begin{array}{c}\text { frequenc } \\
y\end{array}$ & $\%$ & frequency & $\%$ & frequency & $\%$ & $\begin{array}{c}\text { frequenc } \\
y\end{array}$ & $\%$ \\
\hline $\begin{array}{l}\text { Physical } \\
\text { Violence }\end{array}$ & 3 & 7.4 & 4 & 10.2 & 5 & 9.0 & 5 & 9.8 \\
\hline Death & 2 & 4.8 & 3 & 7.7 & 3 & 5.5 & 2 & 4.0 \\
\hline Forensic & 7 & 17.0 & 6 & 15.3 & 8 & 14.6 & 8 & $\begin{array}{c}15 . \\
7\end{array}$ \\
\hline
\end{tabular}


MEDIAJ

\begin{tabular}{|l|c|c|c|c|c|c|c|c|}
\hline Missing & 3 & 7.4 & 3 & 7.7 & 2 & 3.7 & 3 & 5.8 \\
\hline Illness & 6 & 14.6 & 3 & 7.7 & 5 & 9.0 & 6 & $\begin{array}{c}11 . \\
8\end{array}$ \\
\hline $\begin{array}{l}\text { Traffic } \\
\text { Accident }\end{array}$ & 3 & 7.4 & 2 & 5.2 & 4 & 7.3 & 2 & 4.0 \\
\hline $\begin{array}{l}\text { Success - } \\
\text { Talent }\end{array}$ & 1 & 2.4 & 1 & 2.6 & 2 & 3.7 & 2 & 4.0 \\
\hline $\begin{array}{l}\text { Children } \\
\text { Forced into } \\
\text { Crime }\end{array}$ & 4 & 9.7 & 2 & 5.2 & 3 & 5.5 & 4 & 7.8 \\
\hline $\begin{array}{l}\text { Abandonmen } \\
\text { t }\end{array}$ & 2 & 4.8 & 2 & 5.2 & 4 & 7.3 & 4 & 7.8 \\
\hline Accident & 1 & 2.4 & 2 & 5.2 & 3 & 5.5 & 3 & 5.8 \\
\hline Life & 1 & 2.4 & 3 & 7.7 & 4 & 7.3 & 2 & 4.0 \\
\hline $\begin{array}{l}\text { Sexual } \\
\text { Violence }\end{array}$ & 2 & 4.8 & 3 & 7.7 & 5 & 9.0 & 4 & 7.9 \\
\hline $\begin{array}{l}\text { School- } \\
\text { Private } \\
\text { Courses }\end{array}$ & 4 & 9.7 & 3 & 7.7 & 4 & 7.3 & 4 & 7.9 \\
\hline Tabloid News & 2 & 4.8 & 3 & 7.7 & 3 & 5.5 & 2 & 4.0 \\
\hline \begin{tabular}{l} 
Total \\
\hline
\end{tabular} & 41 & 100.0 & 39 & 100.0 & 55 & 100. & 51 & 10 \\
\hline
\end{tabular}

When Table 1 is analyzed, it is seen that forensic news are represented at a very high rate compared to other topics. $17 \%$ of the 41 news articles in Hürriyet newspaper are forensic type of news on the other hand, $14.6 \%$ is the news about the illness and $9.7 \%$ of the children pushed into crime. The lowest rate of news is success / talent, death, life and tabloid news with $2.4 \%$ of representation.

Considering the distribution of news topics according to newspapers, it is seen that $15.3 \%$ of 39 news in Sabah newspaper are in the type of forensic news. $14.6 \%$ of the news is illness and $10.2 \%$ is physical violence. News of sexual violence, school / private courses, life, illness, missing and death have a rate of $7.7 \%$ for each. The lowest rate of news is about success / talent with a rate of $2.6 \%$. Considering the distribution of the news in the Posta newspaper, it is seen that $16.6 \%$ of the 55 news articles in the newspaper are in the type of forensic news. It has a rate of $9 \%$ of the news of physical violence, sexual violence and disease. It is seen that the news type with the lowest rate is the success / talent and missing news with a rate of $3.7 \%$.

It is analyzed that the $15.7 \%$ of 51 news in Sözcü, which is the most highly circulated newspaper in Turkey, are forensic news.11.8\% of the news in Sözcü newspaper was about illness and $9.8 \%$ were physical violence. The news topics with the lowest rate are $4 \%$ success / talent, magazine, death and school classroom news.

When we look at the topics of the news in the four newspapers examined, it is seen that children mostly appear as the subjects of forensic news. This is followed by news of illness and physical 


\section{MEEDIAJ}

violence. It is noteworthy that the rate of child representation in success / talent and life news are extremely low.

Table 2. Distribution of the Representation of Children in the News According to Newspaper

\begin{tabular}{|c|c|c|c|c|c|c|c|c|}
\hline \multirow{2}{*}{$\begin{array}{l}\text { Representation } \\
\text { of Children }\end{array}$} & \multicolumn{2}{|c|}{ Hürriyet } & \multicolumn{2}{|c|}{ Sabah } & \multicolumn{2}{|c|}{ Posta } & \multicolumn{2}{|c|}{ Sözcü } \\
\hline & $\begin{array}{c}\text { frequenc } \\
y\end{array}$ & $\%$ & $\begin{array}{c}\text { frequenc } \\
y\end{array}$ & $\%$ & $\begin{array}{c}\text { frequenc } \\
y\end{array}$ & $\%$ & $\begin{array}{c}\text { frequenc } \\
y\end{array}$ & $\%$ \\
\hline $\begin{array}{l}\text { Children as } \\
\text { Victim of Crime }\end{array}$ & 8 & 19.5 & 6 & 15.3 & 8 & $\begin{array}{c}14 . \\
5 \\
\end{array}$ & 6 & 11.8 \\
\hline $\begin{array}{l}\text { Children as } \\
\text { Suspect }\end{array}$ & 3 & 7.3 & 3 & 7.7 & 4 & 7.3 & 3 & 5.8 \\
\hline Deceased & 1 & 2.4 & 2 & 5.2 & 3 & 5.5 & 3 & 5.8 \\
\hline $\begin{array}{l}\text { Children Living in } \\
\text { Difficult } \\
\text { Conditions }\end{array}$ & 4 & 9.7 & 1 & 2.6 & 5 & 9.0 & 6 & 11.8 \\
\hline $\begin{array}{l}\text { Successful } \\
\text { Children }\end{array}$ & 0 & 0 & & 0 & 2 & 3.7 & 2 & 4.0 \\
\hline Missing Children & 1 & 2.4 & 2 & 5.2 & 3 & 5.5 & 2 & 4.0 \\
\hline Sick Children & 6 & 14.6 & 4 & 10.2 & 5 & 9.0 & 5 & 9.8 \\
\hline Children into Art & 0 & 0 & 1 & 2.6 & 1 & 1.9 & 2 & 4.0 \\
\hline Student & 2 & 4.8 & 4 & 10.2 & 3 & 5.5 & 3 & 5.8 \\
\hline Newborn & 3 & 7.3 & 1 & 2.6 & 4 & 7.3 & 2 & 4.0 \\
\hline Injured Children & 4 & 9.7 & 3 & 7.7 & 4 & 7.3 & 4 & 7.9 \\
\hline Labour Children & 2 & 4.8 & 0 & 0 & 2 & 3.7 & 3 & 5.8 \\
\hline Refugee Children & 2 & 4.8 & 4 & 10.2 & 3 & 5.5 & 3 & 5.8 \\
\hline $\begin{array}{l}\text { Disabled } \\
\text { Children }\end{array}$ & 2 & 4.8 & 3 & 7.7 & 3 & 5.5 & 3 & 5.8 \\
\hline $\begin{array}{l}\text { Well-Known } \\
\text { Children }\end{array}$ & 1 & 2.4 & 2 & 5.2 & 2 & 3.7 & 2 & 4.0 \\
\hline Offspring & 2 & 4.8 & 3 & 7.7 & 3 & 5.5 & 2 & 4.0 \\
\hline Total & 41 & $\begin{array}{c}100 . \\
0\end{array}$ & 39 & $\begin{array}{c}100 . \\
0\end{array}$ & 55 & $\begin{array}{c}00 . \\
0\end{array}$ & 51 & 100.0 \\
\hline
\end{tabular}

When Table 2 is examined, it is seen that children are represented as victims of crime in newspapers more than others. Children were represented as victims of crime in $19.5 \%$ of the news about children in the Hürriyet newspaper. The news reported $14.6 \%$ of children as sick children and $9.7 \%$ as children pushed into crime. The lowest representation rates are the wellknown child, missing child and dead child categories with a share of $2.4 \%$.

It is seen that children are represented as victims of crime in $15.3 \%$ of 39 child-themed news in Sabah newspaper. In the news in Sabah newspaper, children were presented as sick children, refugee children and students with a rate of $10.2 \%$ for each. The lowest representation rates in the Sabah newspaper are the categories of children into the art, children living in difficult conditions and newborns with a share of $2.6 \%$. 
Children were represented as victims of crime in $14.5 \%$ of 55 child-themed news in Posta. In the news in Posta newspaper, $9 \%$ of children were presented as sick children and children living in difficult conditions. The lowest representation rate in the Posta newspaper is the category of children into the arts, with a share of $1.9 \%$.

Children are represented as child victims of crime and children living in difficult conditions, with a rate of $11.8 \%$ of 51 child themed news in Sözcü newspaper. $9.8 \%$ of children were reported as sick children in the news in Sözcü newspaper. The lowest representation rates in Sözcü newspaper are the categories of well-known children, missing children, children into the art and children who have gained success with a rate of $4 \%$.

When the categories of representation of children are examined, it is noteworthy that children are presented as victims of crime in all four newspapers examined. This is followed by the sick child and child representations living in difficult conditions. At least, children were represented as children engaged in art, well-known children, newborns, and children who were successful.

Table 3. Distribution of Presentation of Identity According to Newspapers

\begin{tabular}{|c|c|c|c|c|c|c|c|c|}
\hline \multirow{2}{*}{$\begin{array}{l}\text { Identity of } \\
\text { Children }\end{array}$} & \multicolumn{2}{|c|}{ Hürriyet } & \multicolumn{2}{|c|}{ Sabah } & \multicolumn{2}{|c|}{ Posta } & \multicolumn{2}{|c|}{ Sözcü } \\
\hline & freq & $\%$ & freq & $\%$ & freq & $\%$ & freq & $\%$ \\
\hline Openly Revealed & 24 & 58.5 & 22 & 56.4 & 37 & 67.2 & 28 & 54.9 \\
\hline $\begin{array}{l}\text { Reveled with the } \\
\text { First Letters of } \\
\text { Name and } \\
\text { Surname }\end{array}$ & 7 & 17.0 & 4 & 10.2 & 7 & 12.7 & 11 & 21.5 \\
\hline $\begin{array}{l}\text { Name is Openly } \\
\text { Revealed, Surname } \\
\text { is be the First } \\
\text { Name }\end{array}$ & 3 & 7.3 & 3 & 7.7 & 0 & 0 & 3 & 5.9 \\
\hline $\begin{array}{l}\text { Name is relevant } \\
\text { with the first } \\
\text { Letter; Surname is } \\
\text { Openly revealed }\end{array}$ & 0 & 0 & 0 & 0 & 0 & 0 & 2 & 3.9 \\
\hline $\begin{array}{l}\text { Name and } \\
\text { Surname are not } \\
\text { revealed }\end{array}$ & 5 & 12.2 & 7 & 17.9 & 5 & 9.1 & 3 & 5.9 \\
\hline $\begin{array}{l}\text { Without an } \\
\text { Identity }\end{array}$ & 2 & 4.8 & 3 & 7.7 & 6 & 10.9 & 4 & 7.8 \\
\hline Total & 41 & 100.0 & 39 & 100.0 & 55 & 100.0 & 51 & $\begin{array}{c}100 . \\
0\end{array}$ \\
\hline
\end{tabular}

Considering the way, the identity of the child is given, it is seen that $58.5 \%$ of the 41 news articles published in Hürriyet newspaper reveal the identity of the child. In $17 \%$ of the news, the first letters of the children's names and surnames were revealed. In $12.2 \%$ of the news, children were presented without giving their names and surnames. In $4.8 \%$ of the news, children were presented without identification. 
It is observed that $56.4 \%$ of 39 news articles published in Sabah newspaper reveal the identity of the child. In $10.2 \%$ of the news, the first letters of the children's names and surnames were given. In $17.9 \%$ of the news, children were presented without giving their names and surnames. In $7.7 \%$ of the news, children were presented without identification.

Posta newspaper shows that, it is seen that the identity of the child is clearly stated in $67.2 \%$ of the 55 news in the newspaper. In $12.7 \%$ of the news, the first letters of the children's names and surnames were given. In $9.1 \%$ of the news, children were presented without giving their names and surnames. In $10.9 \%$ of the news, children were presented without identification. It is seen that $54.9 \%$ of the 51 news in Sözcü newspaper gave the identity of the child clearly. In $21.5 \%$ of the news, the first letters of the children's names and surnames were given. In $5.9 \%$ of the news, children were presented without giving their names and surnames. In $7.8 \%$ of the news, children were presented without identification.

Table 4. Distribution of Publication of Children's Photographs According to Newspapers

\begin{tabular}{|c|c|c|c|c|c|c|c|c|}
\hline \multirow{2}{*}{$\begin{array}{l}\text { Children's } \\
\text { Photograph }\end{array}$} & \multicolumn{2}{|c|}{ Hürriyet } & \multicolumn{2}{|c|}{ Sabah } & \multicolumn{2}{|c|}{ Posta } & \multicolumn{2}{|c|}{ Sözcü } \\
\hline & freq & $\%$ & freq & $\%$ & freq & $\%$ & freq & $\%$ \\
\hline Openly Published & 25 & $\begin{array}{c}61 . \\
0\end{array}$ & 21 & $\begin{array}{c}53 . \\
9\end{array}$ & 32 & $\begin{array}{c}58 . \\
2\end{array}$ & 23 & 45.1 \\
\hline $\begin{array}{l}\text { Published with Coved } \\
\text { Face }\end{array}$ & 6 & $\begin{array}{c}14 . \\
6\end{array}$ & 5 & $\begin{array}{c}12 . \\
8\end{array}$ & 5 & 9.1 & 14 & 27.4 \\
\hline $\begin{array}{l}\text { Published with Face } \\
\text { Covered by Hand }\end{array}$ & 3 & 7.3 & 4 & $\begin{array}{c}10 . \\
2\end{array}$ & 6 & $\begin{array}{c}10 . \\
9\end{array}$ & 5 & 9.8 \\
\hline $\begin{array}{l}\text { Published with Eyes } \\
\text { Covered Black }\end{array}$ & 0 & 0 & 3 & 7.7 & 5 & 9.1 & 4 & 7.8 \\
\hline $\begin{array}{l}\text { Published with Back } \\
\text { of Children }\end{array}$ & 4 & 9.7 & 6 & $\begin{array}{c}15 . \\
4 \\
\end{array}$ & 7 & $\begin{array}{c}12 . \\
7\end{array}$ & 5 & 9.8 \\
\hline Total & 41 & $\begin{array}{l}10 \\
0.0\end{array}$ & 39 & $\begin{array}{l}10 \\
0.0\end{array}$ & 55 & $\begin{array}{l}10 \\
0.0\end{array}$ & 51 & 100.0 \\
\hline
\end{tabular}

Photographs were used in all 186 news stories with children themes examined in the study. It is seen that in $61 \%$ of the 41 news published in Hürriyet newspaper, photographs of children are clearly published. In $14.6 \%$ of the news, the photos of the children were posted with their faces closed. It is seen that $9.7 \%$ of the news in the Hürriyet newspaper are published with the back of children. Hürriyet newspaper did not include photographs of children with their eyes taped.

It is seen that in $53.9 \%$ of 39 news published in Sabah newspaper, photographs of children are clearly published. In $12.8 \%$ of the news, the photo of the children was posted with their faces closed. It is seen that $12.7 \%$ of the news in Sabah newspaper are published with their backs. Like the Sabah newspaper and the Hürriyet newspaper, the photos of the children with their eyes are not included.

It is seen that in $58.2 \%$ of 55 news articles published in Posta newspaper, photographs of 


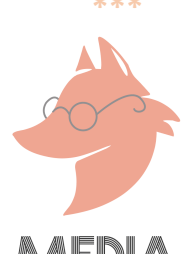

children are clearly published. In $9.1 \%$ of the news, the photo of the children was published with their faces closed. It is seen that $12.7 \%$ of the news in the Posta newspaper are published behind the children. It is seen that $9.1 \%$ of the photographs of children, which are published with eyelets, are included in the Posta newspaper.

It is seen that in $45.1 \%$ of 51 news published in Sözcü newspaper, photographs of children were clearly published. In $27.9 \%$ of the news, the photos of the children were published with their faces closed. It is seen that $9.8 \%$ of the news in Sözcü newspaper are published with the back of children. It is seen that $7.8 \%$ of the photographs of children, which were published with eyes banded, were included in the Posta newspaper.

\section{CONCLUSION}

In this study, which aims to reveal the presentation form of children's news in the context of the ethical responsibility of the media, it was shown that children are mostly presented as the subject of forensic news. Children are represented mostly in forensic news in Sözcü, Hürriyet, Sabah and Posta which have the highst circulation rates in Turkey. This situation indicates that children are represented in newspapers by judicial events. Forensic news is followed by news of illness and physical violence. On the other hand, news categories in which children are represented he least are success/talent and deceased. While it is expected that children will take place in the categories of school / private courses and success / talent the most, the opposite is encountered.

Forensic news is a conscious choice of news type by mass media due to its high news value (Pfeiffer, Windzio, \& Kleimann, 2005). Children are mostly represented in the media only when they are the subject of forensic news. The reason for this is that the combination of juvenile and criminal elements increases the value of the news. Newspapers publish different and newsworthy topics that affect public perception. On the other hand, childhood appears to be the period in which personality is most formed. The fact that the traces of the negative experiences in childhood will be carried by the individual for many years requires that the period should be handled sensitively. Therefore, the media should determine its language in an extremely gentle and naive way in messages where children are subjects.

It is noteworthy that in all of the newspapers examined, the newspapers clearly used photographs of children. The effect of the photograph to reinforce the news in the media is also used in children's news. It can be claimed that no text can create the effect that photography has on people. For this reason, too many photos are used in children's news is seen.

Photographs were used in all of the news in which children were used as subjects. It is striking that the photographs of children who are subjects in forensic news are also used openly. It is 


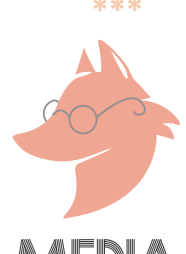

observed that newspapers do not show sensitivity in the use of photographs of children that need to be published with closed faces or eyes in legal news, whereas they are used openly on issues such as school, success, life.

It is noteworthy that more than half of the children in the news are clearly identified. Among this news, there are children involved in crime and children who are subjects of forensic news. However, the identities of children represented in such events should not be publicly disclosed in the media. The news with the name and surname as the initial letter is less than the news where the identity is clearly given. Especially in news where children are suspicious, identities should be given as the first letter of the name and surname. While writing the identities of the children, the type of the news should be taken into consideration and the identities of the children who take part in the forensic news should not be clearly included in the news. While broadcasting in forensic news in a way that explains the identity of children or causes them to be recognized requires criminal sanctions in legal terms, it is considered as an incorrect behavior in the ethical framework.

As a result, journalists need to fully internalize children's rights and ethical responsibility principles since children who are used with various representations in the news are often exposed and suffer due to the language used. One of the most important issues to be addressed is which adjectives are used by children and with which words the word child is combined. Media members are expected to be more careful about this issue and avoid reporting in a way that portrays children as potentially dangerous. In addition to drawing attention to the adverse conditions of children, press members should also consider making solution-oriented publications and news that will mobilize the governments.

\section{REFERENCES}

Ateş, G. A. (2011). Iletişim Alanında Çocuklara ilişkin Ulusal ve Uluslararası Hukuki Düzenlemelerin Değerlendirilmesi. Uzmanlık Tezi. Ankara: Radyo ve Televizyon Üst Kurulu.

Balo, Y. S. (2005). Çocuk Koruma Kanunu ve Uygulaması. Ankara: Seçkin Yayıncılık.

Belsey, A. \& Chadwick, R. (1998). Medya ve Gazetecilikte Etik. İstanbul: Ayrıntı Yayınları.

Bertrand, C. (2004). Medya Etigi. Ankara: Özkan Matbaacılık.

Boulahanis J. G. \& Heltsley M. J. (2004). Perceived Fears: The Reporting Patterns of Juvenile Homicide in Chicago Newspapers. Criminal Justice Policy Review, 15(2), 132-160.

Cheit, R. E. (2002). What Hysteria? A Systematic Study of Newspaper Coverage Of Accused Child Molesters. Child Abuse\&Neglect, 27(6), 607-623.

Collings, S. J. (2002). Unsolicited Interpretation of Child Sexual Abuse Media Reports. Child Abuse\&Neglect, 27(11), 1135-1147. 
Çambay, S. (2016). Yeni Medyada Etik Sorumluluk ve Gazetecilik: Hak Haberciliği. Örs F. (der) içinde, Medya Etik, Sentez Yayıncılık.

Dikmen, A. (1998). Çocuk Haklarına Dair Sözleşme Çerçevesinde istanbul'da Çalışan Çocuklar Üzerine Bir Değerlendirme (Yayımlanmamış Doktora Tezi). İstanbul: Mimar Sinan Üniversitesi Sosyoloji Bölümü.

Gemalmaz, M. S. (2002). Çocuk ve Genç Haklarına ilişkin Ulusalüstü Belgeler. İstanbul: İstanbul Barosu Yayınları.

Girgin, A. (2003). Yazılı Basında Haber ve Habercilik Etik'i. İstanbul: İnkılap Yayınevi.

İnceoğlu, Y. (2008). Bir Üçleme: Çocuk, Medya ve Eğitim. Işık M, Erdem A. (der), içinde, Tüm Yönleriyle Medya ve Iletişim, Eğitim Kitabevi.

İrvan, S. (2005). Medya ve Etik. Alankuş S. (der.), içinde, Medya, Etik ve Hukuk, 2. Baskı. İstanbul: IPS İletişim Vakfı Yayınları. 61-90.

Heffinck, P. (1999) Çocuk Haklarına Dair Sözleşme: Insan Haklarına Dayalı Programlama Yaklaşımı. Küntay, E., Erginsoy, G. (der), içinde, 21. Yüzyıl Karşısında Çocuk ve Genç, İstanbul: Mimar Sinan Üniversitesi Yayınları. 27-39.

Karaosmanoglu, F, (2003). Çocuk Hakları: Dogal Hukuk ve Birlesmis Milletler Çocuk Hakları Sözleşmesi. Akyüz, E., Uluğtekin, S., Baykara Acar, Y. ve Cankurtaran Öntaş, Ö. (der.), içinde, II. Ulusal Çocuk ve Suç Sempozyumu "Yargı Öncesi ve Yargılama Süreci" 10-13 Nisan 2002 Bildiriler, Ankara: Kuban Matbaası. 43-61.

Küntay, E. (2000). Çocuk Hakları ve Aile İçi İliskiler: BM Çocuk Hakları Sözleşmesi Üzerine Bir Yorum. Çitçi, O. (der.), İçinde, Türkiye'de Insan Hakları, Ankara: TODAiE Yayınları. 541-547.

Moeller, S. D. (2002). A Hierarchy of Innocence-The Media's Use of Children in the Telling of International News. Press/Politics, 10(7), 36-56.

Özlü, H. (2002). Türk Medeni Hukukunda Velayetin Kaldırılması. Ankara: Adil Yayınevi.

Pfeiffer, C., Windzio, M. ve Kleimann, M. (2005). Media Use and its Impacts on Crime Perception, Sentencing Attitudes and Crime Policy. European Journal of Criminology, 11(2), 259285.

Salihoğlu, S. (2007). 2006 Yılında Türkiye'de Üç Yazılı Basın Organında Yer Alan Çocuk Haberlerinin Içcerik Analizi Yöntemi ile Değerlendirilmesi. Yüksek Lisans Tezi. İstanbul: İstanbul Üniversitesi.

Selwyn, N. (2003). 'Doing IT for the Kids': Re-examining Children, Computers and the Infomation Society Media, Culture\&Society, (25), 351-378.

Şirin, M. R. (2006). Dersimiz Çocuk. İstanbul: İz Yayıncllık. İstanbul. 


\section{MEDIAJ}

Tiryakioglu, B. (2000). Çocuk Haklarının Korunmasına iliş̧kin Milletlerarası Sözleşmeler ve Türk Hukuku. Ankara: Başbakanlık Aile Araştırma Kurumu Yayınları.

Tokgöz, O. (2000). Temel Gazetecilik. 4. Baskı. Ankara: İmge Kitabevi.

Türkiye Gazetecilik Hak ve Sorumluluk Bildirgesi. Access:20.06.2020

https://www.tgc.org.tr/bildirgeler/t\%C3\%BCrkiye-gazetecilik-hak-ve-sorumlulukbildirgesi.html

UNICEF (2005). The Media and Children's Rights. UNICEF. Access:12.10.2020

https://www.unicef.org/montenegro/en/reports/media-and-childrens-rights 